\title{
Exploring the Relationship of Service Quality on Customers Delight in Selected Restaurant of Laguna, Philippines
}

\author{
MICHAEL BHOBET B. BALUYOT, DHM ${ }^{1}$, ANICIA C. PAMPOLINA, MSHRM ${ }^{2}$ \\ ${ }^{1}$ College of Industrial Technology, Food and Apparel Technology Department, TECHNOLOGICAL UNIVERSITY OF \\ THE PHILIPPINES MANILA, PHILIPPINES. E-mail: michaelbhobetbaluyot@yahoo.com: \\ ${ }^{2}$ College of Hospitality Management and Tourism, LAGUNA STATE POLYTECHNIC UNIVERSITY-SPCC, \\ PHILIPPINES. E-mail: anicia.pampolina@Ispu.edu.ph:
}

\begin{abstract}
This paper aimed to determine customer experiences in the pandemic situation at a local restaurant in Laguna, Philippines, and to demonstrate that there are now beyond eating experiences available in that area. The study included 150 customers from Laguna's different restaurants. The SERVQUAL Model and Customer Delight Model serve as the foundation for this study endeavour. Pearson $r$ was used to calculate the correlation coefficient. The five dimensions used in the study are reliability, assurance, tangibles, empathy, and responsiveness. Based on the findings, personal attention and creating an emotional connection with customers are essential in interacting with customers and delivering consistent service. The findings revealed that the total customer delight experience was moderately delighted. Furthermore, the findings have shown a correlation coefficient $r$ of 0.720 , which indicates a high level of correlation. These findings demonstrated that high-quality service always equates to high-quality delight and happiness. Findings revealed that customers want value and the whole experience rather than just the quality of the food. Customers are influenced by how they are handled at all stages of their dining experience. The study's findings serve as a foundation for future growth, demonstrating that a small restaurant can compete in the fast-growing restaurant industry by providing excellent customer service.
\end{abstract}

Keywords: Service Quality; Customer Satisfaction; Customer Delight; SERVQUAL Model; Customer Delight Model.

JEL Classification: D0, E7, L1, L2, M1 


\title{
Exploración de la Relación de la Calidad del Servicio con el Placer de los Clientes en un Restaurante Seleccionado de Laguna, Filipinas
}

\author{
MICHAEL BHOBET B. BALUYOT, DHM ${ }^{1}$, ANICIA C. PAMPOLINA, MSHRM ${ }^{2}$ \\ ${ }^{1}$ College of Industrial Technology, Food and Apparel Technology Department, TECHNOLOGICAL UNIVERSITY OF \\ THE PHILIPPINES MANILA, PHILIPPINES. E-mail: michaelbhobetbaluyot@yahoo.com \\ ${ }^{2}$ College of Hospitality Management and Tourism, LAGUNA STATE POLYTECHNIC UNIVERSITY-SPCC, \\ PHILIPPINES. E-mail: anicia.pampolina@lspu.edu.ph
}

\begin{abstract}
RESUMEN
El objetivo de este trabajo era determinar las experiencias de los clientes en la situación de pandemia en un restaurante local de Laguna (Filipinas) y demostrar que en la actualidad hay más experiencias gastronómicas disponibles en esa zona. En el estudio participaron 150 clientes de diferentes restaurantes de Laguna. El Modelo SERVQUAL y el Modelo de Deleite del Cliente sirven de base para este esfuerzo de estudio. Se utilizó la $r$ de Pearson para calcular el coeficiente de correlación. Las cinco dimensiones utilizadas en el estudio son fiabilidad, garantía, tangibles, empatía y capacidad de respuesta. Según los resultados, la atención personal y la creación de una conexión emocional con los clientes son esenciales para interactuar con ellos y ofrecerles un servicio coherente. Los resultados revelaron que la experiencia total de deleite del cliente fue moderadamente encantadora. Además, las conclusiones han mostrado un coeficiente de correlación $r$ de 0,720 , que indica un alto nivel de correlación. Estos resultados demostraron que un servicio de alta calidad siempre equivale a un deleite y una felicidad de alta calidad. Los resultados revelaron que los clientes quieren el valor y la experiencia completa, más que la calidad de la comida. Los clientes se ven influidos por el trato que reciben en todas las fases de su experiencia gastronómica. Las conclusiones del estudio sirven de base para el crecimiento futuro, ya que demuestran que un restaurante pequeño puede competir en el sector de la restauración, que está creciendo rápidamente, ofreciendo un excelente servicio al cliente.
\end{abstract}

Palabras clave: Calidad del servicio; Satisfacción del cliente; Deleite del cliente; Modelo SERVQUAL; Modelo de Deleite del cliente.

Clasificación JEL: D0, E7, L1, L2, M1 


\section{Introduction}

Various international and national efforts have been launched in response to the economic crisis created by the COVID-19 health pandemic, supplemented by particular measures done by different foodservice businesses operating in the Philippines. In line with today's competitive foodservice industry, businesses must have a sensitive awareness of the situation and react swiftly to provide products and services that meet customers' expectations. Companies' value long-term and reliable client relationships, and customers expect to get various benefits when they buy regularly. The quality of a service, independent of whether it fulfills consumer expectations, may have an impact on customer satisfaction. In addition to assisting an organization in reaching its full potential and becoming a market leader, it will also assist the business in avoiding obsolescence by keeping it current. The level of service provided is a good predictor of customer satisfaction. When service performance falls short of expectations, consumers get dissatisfied. (Pandey et al., 2021)

Following the COVID-19 outbreak, Verdict (2020) offers an assessment of the impact on the economic stability of the foodservice operators. According to the findings of the evaluation, the pandemic must have a devastating effect on operators. According to the majority of respondents, many food operators suffered losses and had to endure lengthy recovery periods. However, 28 percent believed their impact was severe but only lasted for a few months, followed by 15 percent who thought that the effect was powerful and resulted in poor market demand for an extended period following the pandemic.

One of the most pressing issues facing today in the foodservice industry is guaranteeing and keeping customer happiness. In the fight for competitive differentiation and customer retention in this current pandemic situation, service quality and customer happiness are becoming more important in sustaining the company's economic standing. The main objectives, according to Markovic et al. (2011), are to evaluate restaurant customers' expectations and perceptions, as well as to identify important aspects of perceived and anticipated restaurant service quality.

In the tight competition of hospitality businesses, service quality and customer satisfaction are critical to success and survival. Throughout the previous decades, the concepts of service quality and customer pleasure were extensively researched and used in marketing texts and activities. Businesses have been compelled to provide additional services and offers to their customers since the beginning of the consumption period. As consumption shifts to post-consumption, businesses must provide more services and provide more to their consumers. Aside from continuously improving service quality, ongoing innovation is also required in the current pandemic situation, given the market's many competitors. Customers are always on the lookout for new things to do and see. Managers may develop or remodel picture spots on a regular basis to meet the needs of customers (Angmalisang, 2021). In recent decades, practitioners and academics have placed a strong emphasis on customer happiness and service quality. Both concepts have a significant impact on business outcomes and customer behavior. The worldwide market trend has moved dramatically away from agriculture and service industries (Asian Development Bank, 2007). To satisfy customers, all service businesses, especially those in the hotel industry, are working hard to improve service quality. Hoteliers are increasingly concentrating on quality standards to meet their customer's basic needs and expectations. If hotel owners know and understand their customers' wants and aspirations, they are more likely to anticipate and fulfill them (Devi Juwaheer \& Lee Ross, 2003, Lopez et al, 2021).

Customer satisfaction was most affected by front-line employees' responses, followed by price and food quality (in that order). The restaurant's appearance and décor have no bearing. Full-service restaurants prioritize service quality or responsiveness, price, and food quality or consistency (Saad Andaleeb and Conway 2006). According to Danish Habib and Attiq's (2020) list of many research related to revenue from operations, literature on the impact of employee's relevant attitudes on customer response and efficiency is limited. They respect the analytical perspective and conduct empirical evaluations of the perceptual and emotional aspects of customer responses and service. 
Customer expectations management, product design management, service customer education, developing a total quality management program, achieving continuous quality through automation, and conducting periodic reviews of the operation's procedures, personnel, and property are just a few ways SERVQUAL can be used as an assessment tool in a restaurant. An assessment of a restaurant's strengths and weaknesses may then be utilized to successfully run the company (Nduba and Supinit 2015).

Customer satisfaction has long been used to gauge a company's long-term performance. According to studies, the connection between enjoyment and significant behavioural effects is not always obvious. The term "customer pleasure" emerged as a consequence of the dissatisfying low connection between customer happiness and key KPIs. Rather than meeting the client's expectations, pleasure typically includes a level of surprise that surpasses the client's expectations. Customer joy, as opposed to contentment, has a stronger connection to actual results. Customers that were happy had higher levels of loyalty and commitment, as well as higher levels of patronage and willingness to spend, according to research conducted by Barnes et al. (2011).

However, there is still concern about the concept of customer delight. Although much qualitative research has been conducted on the antecedents of pleasure production, few empirical studies have been conducted on these factors. This study employed descriptive quantitive correlational research approach. Its parameters were based on the previous studies ( Ahorro, et al, 2021, Charernnit, et al, 2021, De Souza, et al, 2021, Lopez, et al, 2021, Magulod Jr, 2017, , Magulod Jr, 2019, Magulod, et al, 2021, Magulod, et al, 2020, Nuncio, et al, 2020). Practitioners need more guidance than just being told to "please" the customer. Amid this problem, it may be helpful to know if a slew of common issues limits the hospitality industry's ability to cope with today's uncertainties, given the potential that a standard set of problems may drive industry-wide solutions. Consequently, this research aims to discover the particular variables that affect customer satisfaction within management's control.

\section{Service Quality and Customer Delight}

Due to the COVID-19 epidemic, economic activity has plummeted in several nations, resulting in an economic catastrophe that is currently impossible to quantify. Telukdarie and Mohlala (2020) described the global food and beverage business as being segmented based on the COVID-19 impact research on the competitiveness in the food and beverage industry online food chain and offline food chain. Offline food chain, which is entirely shut restaurants and cafes, is one of COVID-19's repercussions. The present situation puts pressure on the hospitality business, particularly the foodservice industry, to create bold strategic plans to address and mitigate the global economic crisis.

Previous studies have established various measures to evaluate service efficiency in the new normal, particularly in the hospitality industry. Much research has been conducted that indicates the essential successful element of any service business in the age of globalization and the consistency of tickets on the market. These measures also highlight the importance of individual or group service characteristics such as physical world quality, interactional quality, and result quality (Namkung and Jang, 2007). Researchers have indicated that these measures are linked to main outcome variables such as customer satisfaction and behavioral intentions in many studies.

Practitioners initially proposed the idea of customer delight, arguing that although contentment is essential, it may not be enough to beat rivals and grow sales. They advocated delighting consumers to generate greater loyalty and loyalty-driven profit, casting doubt on the returning rate of pleased groups. To remain a top option in the minds of consumers, the company must constantly enhance its products in a volatile industry. Customers are also becoming more intelligent, and they want better goods and services. These recommended companies must take a step ahead to surpass consumer expectations, and "delight" is one of the most important metrics to track this effort. A growing body of studies has shown a connection between profit and loyalty, with pleased consumers being the real loyalists. (Kwong and Yau, 2002) Delight is seen as a distinct construct with its own set of antecedents and effects. Previous research has indicated that surprise is a crucial antecedent of pleasure and 
triggered by strong positive disconfirmation. Positive affect and arousal are accompanied by disconfirmation, both of which impact consumer pleasure. Similarly, Kumar et al. (2001) suggested that customer delight may be measured.

Comprehended by investigating the cognitive evaluation on two levels, the primary assessment incorporates goal relevance, goal congruence, and different kinds of ego involvement. Secondary assessment aspects include volition, future expectations, reactivity, expected effort, coping capacity, and personalization. Both of these writers modeled intention due to customer pleasure but with a greater degree of favorability than happy consumers. (Kwong and Yau, 2002)

This study is based on Torres and Kline's (2012) SERVQUAL Model and the Customer Delight Model. During a comprehensive research program performed between 1983 and 1988, a trio of American authors, A. Parasuraman, Valarie A. Zeithaml, and Len Berry, developed the gaps model of service quality. The model specifies the main elements (or components) of service quality, as well as a scale for evaluating service quality (SERVQUAL) and possible causes of service quality problems. Initially, the model's creators identified ten elements of service excellence. Despite this, following testing and retesting, many of the factors were found to be closely related, lowering the total number of dimensions to five: dependability, assurance, tangibles, empathy, and responsiveness. These five traits are said to represent elements of great service across a wide range of companies and circumstances. The capacity to deliver the promised service on a constant and adequate basis is described as reliability. Assurance refers to an employee's ability to inspire trust and confidence in others via their competence and civility. Tangibility is enhanced through physical buildings, equipment, and personnel appearance. Customers are given dedicated, one-on-one attention by the company. The aim of a business is to help customers and provide timely service, which is referred to as responsiveness. According to the idea, various variables linked to customers, employees, and the company may account for customer satisfaction.

The conceptual framework below defines the approach that will be used to guide this study. The SERVQUAL approach is suitable for assessing service quality and customer joy in select Laguna restaurants that use service quality dimensions that have been modified to incorporate customer delight as a critical component of success in the foodservice industry's service quality. The model acknowledges Customer Delight as a component of service quality and provides a scale for assessing service as a significant factor in the service quality of the restaurant sector.

Figure 1 Conceptual Framework of the Relationship of Service Quality to Customer Delight

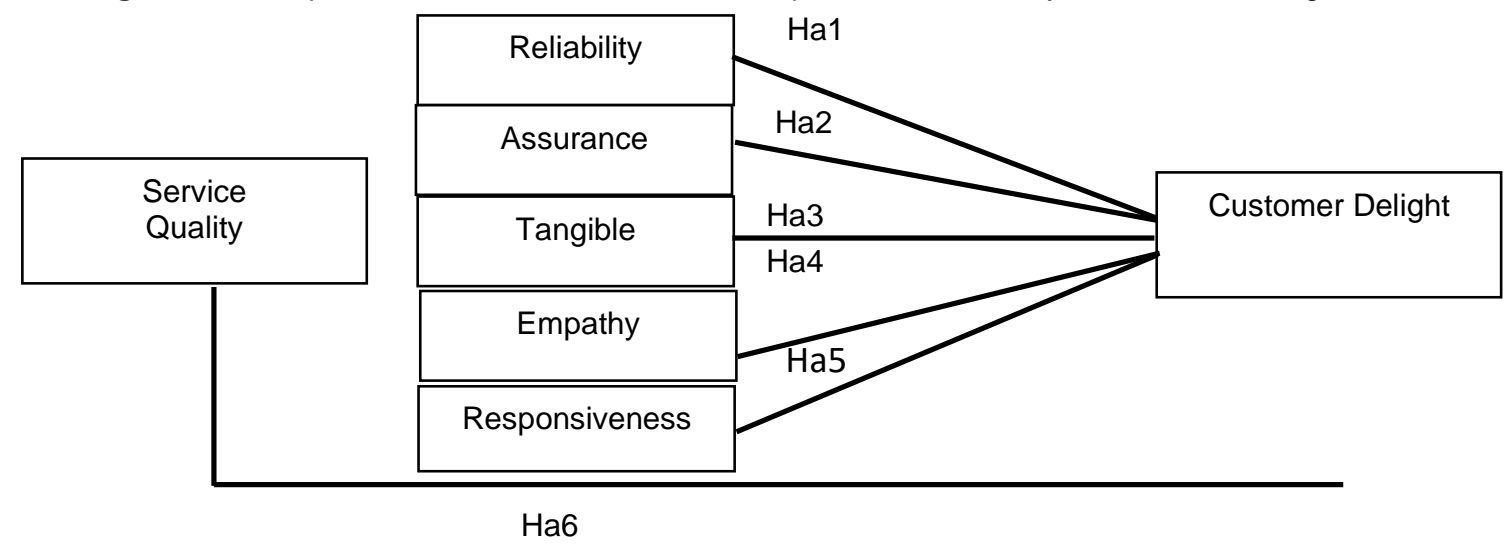

Source: Modified Model from Parasuraman et al. 1988 and Torres and Kline 2012

In the restaurant business, SERVQUAL is used to evaluate customers' expectations and perceptions of service quality, as well as their satisfaction. Quality of service and what a consumer expected to experience, feel, or see define customer satisfaction. As a result, expectations of excellent service outweigh perceptions. When the level of service quality is greater, customers are more likely to be satisfied with it. When expectations and perceptions are in line, service quality is generally satisfactory, resulting in Customer Delight. The conceptual framework describes the technique that will be utilized to conduct this study. The research will be based on the findings of the framework. Service quality 
metrics are appropriate for evaluating service quality and customer satisfaction in certain Laguna restaurants. In addition to Customer Delight, the model provides a scale for assessing service as a key factor in the restaurant industry's service quality.

\section{Assessment of Customer Perceived Service Quality}

Presented in Table 1 is the descriptive summary of the assessment of the casual dining restaurant customer's in terms of the service quality dimensions.

Table 1 Summary of the Assessment of the Customer' Perceived Quality per Dimension

\begin{tabular}{llll}
\hline Dimension & Mean & Std. Deviation & Interpretation \\
\hline Assurance & 4.392 & .5806 & Agree \\
Responsiveness & 4.269 & .6721 & Agree \\
Empathy & 4.236 & .6034 & Agree \\
Tangibles & 4.105 & .6203 & Agree \\
Reliability & 4.110 & .6357 & Agree \\
\hline OVERALL RESULTS & $\mathbf{4 . 2 2 2}$ &. $\mathbf{6 2 2 4}$ & AGREE \\
\hline
\end{tabular}

The summary reflected significant findings wherein the five dimensions studied in this paper are the necessary requirements to assess the delight of the customers in the restaurants. As shown in the table, the perceived assessment of the customers in all criteria of service quality dimensions is Agree. This only implies that there are still lacking qualities needed to meet customer satisfaction and customer delight.

Based on the study of Verma (2003), consumer pleasure has become a significant area of study due to the realization that enjoyment alone does not ensure important customer behaviors such as loyalty. Pleasure, as opposed to satisfaction, has been shown to have a substantial effect on both psychological and behavioral consumer traits. Companies that delight their customers, for example, may form deeper emotional bonds with them, as well as higher degrees of loyalty, commitment, willingness to pay, and word-of-mouth marketing (Barnes et al., 2016). Practitioners first introduced the concept of customer joy, saying that although satisfaction is essential, it may not be enough to outperform competitors and increase sales. They recommended pleasing customers to increase loyalty and loyaltydriven profit, casting doubt on the return rate of delighted groups. To maintain its position as a top choice in customers' eyes, the business must continuously improve its goods in a changing environment. Customers are also growing more sophisticated, and they want higher-quality products and services. All of this indicates that the company has to take a step forward to customer expectations, and "pleasure" is one of the most important indicators to monitor. An increasing number of studies have shown a link between profit and loyalty, with satisfied customers being the true loyalists. Kwong and Yau (2002) and Rao and Sahu (2002) investigated customers' views of service quality and satisfaction (2013). The study was able to uncover five elements of service quality as well as consumers' expectations and impressions of these services by focusing only on front-office employees. This study looked at the gap between customers' expectations and perceptions of frontoffice service quality. The overall mean perception score in all categories was higher than anticipated, resulting in a positive SERVQUAL gap. According to the findings of this study, the majority of respondents rated tangibility as the most significant satisfaction. They found that focusing on certainty and reliability may enhance a hotel's service quality. Restaurants play important roles in terms of the degree of operation, product quality, environment, and price, from fast food to gourmet dining. The food and cleanliness have both contributed to the excellent quality of service. (DiPrieto, 2017). 


\section{Customer Delightful Experiences}

Based on the study's results, the total customer delight experience was moderately delighted, as indicated in the table. The lowest mean score was 3.07, saying that "I am satisfied with the cost of meals and services than I anticipated. It is within my/our budget." And the highest mean score was "I am inclined to recommend the restaurant to others based on my experience." with a mean rating of 3.44 .

Table 2 Descriptive Summary of the Customer's Delightful Experiences to different Restaurants

\begin{tabular}{|c|c|c|c|}
\hline Delightful Items & Mean & $\begin{array}{l}\text { Std. } \\
\text { Deviation }\end{array}$ & Mean Interpretation \\
\hline $\begin{array}{l}\text { 1. I am more likely to inform others about my positive } \\
\text { dining experience. }\end{array}$ & 3.44 & .519 & Moderately Delightful \\
\hline $\begin{array}{l}\text { 2. I am very much satisfied with the food, taste and } \\
\text { quality. I love the food it completes everything I need in } \\
\text { one great meal. }\end{array}$ & 3.42 & .578 & Moderately Delightful \\
\hline $\begin{array}{l}\text { 3. I am more comfortable with the overall surroundings } \\
\text { in the restaurant. }\end{array}$ & 3.40 & .535 & Moderately Delightful \\
\hline 4. In this restaurant, I had unexpected joy and surprise. & 3.15 & .639 & Moderately Delightful \\
\hline $\begin{array}{l}\text { 5. I am pleased with cost of food and services than I } \\
\text { expected. It fits my/our budget. }\end{array}$ & 3.07 & .687 & Moderately Delightful \\
\hline OVER ALL DELIGHT & 3.29 & .591 & ERATELY DELIGHTFUL \\
\hline
\end{tabular}

Torres and Kline (2012) conducted research in the hotel sector to create a typology of customer enjoyment. As a result, it finds similarities in how hotels handle their customers. Content analysis is used to analyze client feedback letters from various hotels. Two raters classified the letters using a codebook, and the inter-rater reliability was evaluated. According to the findings, the most often cited codes were taking care of the guest's requirements, outstanding politeness, staff professionalism, workers going above and beyond the call of duty, and problem-solving abilities. The authors suggest the following enjoyment categories based on this information: satisfying joy, charismatic delight, professional delight, comparative delight, and issue resolution delight. It was also discovered that an organization's culture influences the kinds of pleasure that are most common.

Kwong and Yau's (2002) research mentioned that delight is seen as a distinct concept with its antecedents and effects. Previous research has indicated that surprise is a crucial antecedent of pleasure and that it is triggered by strong positive disconfirmation. Positive affect and arousal are accompanied by disconfirmation, both of which impact consumer delight.

Similarly, Kumar et al. (2001) suggested that customer delight may be understood by looking at the cognitive evaluation in two levels. The primary assessment incorporates aspects of goal relevance, goal congruence, and different kinds of ego involvement. Secondary assessment aspects include volition, future expectations, reactivity, expected effort, coping capacity, and personalization. Both of these writers modeled intention due to customer pleasure but with a greater degree of favorability than happy consumers.

The existence of three satisfaction categories: bivalent satisfiers, monovalent satisfiers, and monovalent dissatisfies, explains why dissatisfaction/satisfaction is not a binary. While bivalent satisfiers may generate Satisfaction and discontent, monovalent satisfiers are "bonus" items that do not add to customer displeasure. On the other hand, Monovalent dissatisfies are fundamental characteristics that do not contribute to Satisfaction but create discontent when unmet. According to the researchers, the anchors of consumer happiness include anger to pleasure and dreadful to delight. Others use words like "totally angry" to describe the strength of their emotions. 
A number of internal and external variables impacted the brand's success. According to lyer et al. (2020), greater levels of brand identity, engagement, and citizenship are symbolically linked to higher levels of brand identification, engagement, and citizenship. Internal branding is obvious from the standpoint that intellectual capital is one of a company's most valuable assets.

\section{Relationship of the Service Quality Indicators to the Delight of the Customers}

As shown in the table, the correlation matrix and Pearson $r$ Correlation were used to test the null hypothesis that there is no significant relationship between service quality attributes and customer satisfaction.

Table 3 Relationship of the Service Quality Indicators to the Delight of the Customers

\begin{tabular}{cccc}
\hline Service Quality & Pearson r & r Interpretation & Decision \\
\hline Reliability & 0.639 & High & r Is Significant \\
Assurance & 0.547 & Moderate & r Is Significant \\
Tangibles & 0.515 & Moderate & r Is Significant \\
Empathy & 0.598 & Moderate & r Is Significant \\
Responsiveness & 0.569 & Moderate & r Is Significant \\
\hline $\begin{array}{c}\text { OVER ALL SERVICE } \\
\text { QUALITY }\end{array}$ & $\mathbf{0 . 7 2 0}$ & HIGH & r IS SIGNIFICANT \\
\hline
\end{tabular}

The findings revealed a correlation coefficient $r$ of 0.720 , which indicates a high level of correlation. These findings demonstrated that high-quality service always equates to high-quality delight and happiness. The Pearson $r$ correlation index of service quality indicators to customer delight was calculated. The values of $r$ were calculated in MS Excel and shown in the table. The research includes reliability as one of the service metrics. The service crew's problem-solving abilities, talents and professionalism, error-free services, and efficient and effective service are examples of reliability. The variables Reliability and Customer Delight were shown to be strongly linked, suggesting that a highreliability value for the restaurant's customers would also imply a high score in the respondents' Delight. Customers' delightful experiences include pleasure with the restaurant's cuisine flavor and quality and comfort with the surroundings and price.

To get a better knowledge of the determinants of customer pleasure from the consumer's viewpoint. As a result, this study focuses on three main issues: Determining the types of employee behaviors that lead to Delight in a service encounter; Determining consumers' expectations before their delightful meeting, and; Resolving the differences between good and pleasurable customer encounters (Barnes et al., 2011)

Findings revealed that employee effect and employee effort seem to be the essential variables in generating pleasure. In terms of satisfaction, these characteristics were both rated higher than staff talents. Notably, prior research does not seem to have wholly exposed the potency of these variables. Furthermore, this study supports the use of both the disconfirmation paradigm and the less-used needs-based approach for assessing customer pleasure.

In the research conducted by Qin and Prybutok (2009), they examined the connection between service quality, food quality, perceived value, customer satisfaction, and behavioral intentions in fastfood restaurants. The study's tangibles, such as dependability or responsiveness, recovery, certainty, and empathy, were all key components. Customer satisfaction was mostly determined by the quality of service and the quality of the meal. The perceived value construct's insignificance may be attributed to its homogenous nature within the fast-food restaurant group rather than its relevance within food service. The tangibles described in this article include the availability of parking spots and chairs, a pleasant atmosphere, modern equipment, current materials, and the restaurant's attractive look. 
Customers' pleasure was linked with tangibles, with a Pearson $r$-value of 0.515 , indicating a moderate and favorable connection. The significance of the value of $r$ was also determined using MS Excel, resulting in the conclusion that the relationship between restaurant tangibles and customer pleasure is positive, moderate, and statistically significant. Finally, tangibles are one of the elements that may influence consumer happiness. This means that the more the tangibles supplied by restaurants, the greater the consumers' pleasure.

Based on the study of Dominici and Palumbo (2013), who performed research to evaluate the customer satisfaction needs for Sicilian hotels to propose and weigh a set of essential characteristics that hotel managers should consider to develop a compelling offer. According to the research findings, just two criteria (must-have requirements) are required to meet the fundamental demands of hotel guests: multilingual personnel and air conditioning and heating. Because customers take these things for granted, their existence does not improve customer happiness, but their removal generates significant discontent. A three-star hotel in the city center, for example, has a high percentage of international visitors, necessitating the hiring of multilingual personnel. Given how hot Sicilian summers are, air conditioning and heating are essential for visitors' comfort. In other words, even in low-cost three-star hotels, air conditioning and heating, as well as multilingual personnel, are required. Although their presence does not improve consumer satisfaction, their removal would have a significant negative impact.

According to Ryu et al. (2012), three foodservice quality aspects, such as physical environment, food, and service, affect restaurant image, customer perceived value, customer satisfaction, and behavioral intentions. According to the results of structural equation modeling, the physical atmosphere, cuisine, and service are all significant factors in creating a restaurant's image. The physical setting and the quality of the food also impacted consumer perceived value. The idea of the restaurant was also shown to be a strong predictor of customer perceptions of value. In addition, the findings showed that consumer perceived value is a major driver of customer satisfaction and a strong predictor of future behavior.

In this study, the idea of empathy is defined as restaurants giving individualized attention, recognizing customers' requirements, and demonstrating care in addition to the full meal package. When the restaurant's empathy was compared to the customers' pleasure, the correlation value was found to be 0.598 . To be classified as having a strong correlation, the value must be somewhat lower. This seems to imply that the connection between empathy and pleasure is positive and nearly high. Finally, the researcher can confidently state that the link between empathy and customer pleasure is statistically significant, positive, and moderate. The researcher may also infer that when restaurants provide a high degree of empathy to their clients, the latter can be anticipated to be delighted.

According to Wilkins et al. (2007), there are three kinds of service quality: physical product, service experience, and food and beverage quality. Kimpakorn and Tocquer (2009), on the other hand, emphasized the growing importance of service quality in light of the need for staff motivation to maintain the brand image/promise. According to Chang and Chieng (2006), customers' ratings of service quality were significantly linked to the personality characteristics of frontline workers. Employees that like serving others and their work, as well as employee honesty, integrity, and the capacity to cope with crises, are all essential components of providing great service, according to Ineson et al. (2011).

\section{Challenges of Selected Restaurants in Achieving Customer Delight}

Centered on the survey, Table 4 shows the challenges faced by the casual dining restaurant in meeting customer delight. This section enumerated the challenges as provided by the customers of the selected restaurants in Laguna City, Philippines. 
Table 4 Challenges Faced and Experienced Encountered by the Restaurants in Achieving Customer Delight Challenges and Experiences Identified of the Restaurant

\begin{tabular}{cc} 
Frequency & Rank \\
10 & 1.5 \\
10 & 1.5 \\
3 & 3 \\
2 & 5 \\
2 & 5 \\
2 & 5 \\
\hline
\end{tabular}

1. Guest Complaints

2. Taking Care of Loyal Customers

3. Menu Pricing

4. Training Staff Service

5. Marketing Strategy

6. Competition

Note: Multiple Responses

Based on the results of the researcher's interview with restaurant workers, $100 \%$ of the respondents said they had received visitor complaints. The most frequent concern of the customers was the serving orders were taken and who would be served first. Innovative approaches to consumers and listening to their issues are essential for customer experiences and improvement. When a problem occurs and cannot be handled by the employees, provide a customized response from the management to know they were paying attention. The blast technique was used, which entails believing in people, listening, apologizing, satisfying, and thanking them.

According to the results of the researcher's discussion with restaurant workers, $70 \%$ of those polled said they had never faced such difficulties. Most of the customers know that the price of the menu is high in valuing the ingredients of the menu. The customer's first concern before entering a restaurant is the menu pricing because menu pricing includes food expenditures as well as other restaurant expenses. It is critical to preserve the food's high quality. Ingredients mainly were sourced from highend marketplaces rather than the local market. If feasible, take the time to explain to consumers why menu prices must be adjusted in response to market developments.

Based on the result of the findings, $80 \%$ of respondents said they do not find training employees difficult. The significance of recruiting and training the appropriate staff is well understood by most successful restaurant operators. Pay special attention to identifying positive characteristics in workers and let them understand the value of training, objectives, and rewards. Ascertain if employees are passionate and driven to achieve the objectives and stick to the restaurant's idea. The restaurant manager/owner should be a role model, dedicated, motivating, and skilled at operating the business.

Findings also revealed that $80 \%$ of respondents said that marketing strategy is not a problem in attaining customer satisfaction. Customers and social media users who have had similar experiences were the ones who helped them learn about the restaurant since there were no ads or other marketing tactics. Some consumers leave comments on the website's reviews page, which greatly benefits them in terms of marketing. (Hartono et al., 2018)

In the interview conducted by the researchers, $80 \%$ of the respondents said no, and that they do not face competition from other restaurants. To ensure that the restaurants can compete, respondents ensure that it has a distinctive selling feature that enables consumers to distinguish it from the competition. Go above and above by providing a one-of-a-kind cuisine and outstanding customer service. The business must begin to consider an identity that establishes a different emotional connection with its consumers. Jian et al. (2021) supported this in their study that consumer behavior is the way in which consumers purchase and use products and services based on a variety of factors. Moreover, the client's decision to purchase a product is based on the kind of product. The level of risk associated with the exchange also has an effect on its performance. More expensive goods will have a greater effect on the customer's purchasing decisions. Complex purchase behavior, dissonancereducing purchasing behavior, repeated purchasing behavior, and assortment searching for activity are only a few instances of these activities. 
The findings of the study also revealed that $100 \%$ of the respondents said yes, they have loyal clients that keep coming back. Consumer loyalty is becoming more challenging to retain, based on past experiences, and this is one of the most significant problems in the restaurant industry today. However, providing a one-of-a-kind, quick, and polite service may positively review the restaurant. Well-trained serving personnel will provide the level of service that customers demand, if not more. Customers are more concerned with the whole experience than with the quality of the meal. Finally, consumers want their food to be delivered quickly and their orders to be precise and consistent, in addition to a customized experience. Restaurants that provide consistent, individualized customer service face a lot of pressure to improve customer happiness, which leads to customer pleasure.

\section{Conclusion}

In a competitive environment in this time of pandemic situation, providing quality to consumers necessitates improving a customer's experience and delight constantly. However, research suggests that just pleasing consumers are insufficient to keep them since even pleased customers defect significantly in many sectors.

Consumer delight has emerged as an essential topic of research as it has become clear that contentment alone does not guarantee crucial customer behaviors such as loyalty. Customer satisfaction varies substantially from delight as a concept. Pleasure is a more emotional feeling than happiness, which is a more cognitive emotion. Pleasure, on the other hand, necessitates the creation of a new schema, while contentment is schema-free. Satisfaction may also have a shorter memory trail, which may be related to the level of surprise. Firms must investigate the optimum mix of product/service characteristics that leads to the highest degree of customer pleasure. Alternative customer pleasure delivery methods must be evaluated in terms of cost/benefit, return on quality, competition's capacity to replicate a particular approach, and a firm's ability to cope with increased expectations connected with each strategy.

Based on the results of the study, the evaluation degree of relationship of service quality as assessed by the respondents in the reliability, assurance, tangibles, empathy, and responsiveness, the respondents are consistent in ranking the service characteristics as "AGREE." There is still much to consider in creating client pleasure, such as the consistency of customer service encounters. Customers are influenced by how they are treated at each stage of their dining experiences. The restaurant customers must be handled in the manner in which you would want to be treated.

Guest complaints, menu pricing, training personnel, restaurant marketing tactics, and competitiveness are among the challenges and experiences of the management and employees. Restaurant management may explore some of the following alternatives to encourage future thought on these problems and difficulties.

- Guest Complaint. If a restaurant fails to keep a promise, the business loses customers' confidence, and without trust, the company loses client loyalty. The human aspect is sorely missing in an era of robotic customer service representatives and soon-to-be self-driving cars.

- Menu Prices. The restaurant business is no exception. Guests who visit the restaurant expect to enjoy excellent food and pay a reasonable price for it. Because they are less worried about the costs, seeing the "Charm Prices" on the menu presented in this manner tempts them to buy more. The concept is just a psychological play; when consumers see a price like 99 , their brains immediately interpret it closer to 0 than 1 . As a result, people believe they are getting a good bargain by purchasing those goods.

- Training Personnel. Building a future for management and employees is one way to professionalizing the business. Human resource strategy specialists create leadership and customer service models and strategies to assist managers and employees in progressing and advancing. More emphasis on developing outstanding customer service skills in issue solving and dispute resolution may improve the talent pool of industry workers. 
- Marketing Tactics. Collaboration with internet food applications is undeniably advantageous to a restaurant's marketing strategy. Through gamification and customer loyalty programs, which give customers a free purchase or a discount for visiting a specific number of times, partnering with internet applications encourages people to check out the restaurant.

- Competition. Sustainability is increasingly widely recognized as a critical success element in a firm's long-term business plan. Companies that integrate sustainability into their marketing strategy have a distinct competitive edge over other organizations. Innovation is the key to development, especially in economic crises, and savvy businesses will see sustainability as the next frontier of innovation.

\section{References}

1. Ahorro, A. M. T., David, M. R. T., Molina, J. M. V., Pangilinan, A. B. Y., \& Arcinas, M. M. (2021). Correlations between the Senior High School Grade 12 Students' Perception of School Classroom Climate and Compliance to School Classroom Norms in a Private University in Manila, Philippines. International Journal of Multidisciplinary: Applied Business and Education Research, 2(4), 274-284.

2. Angmalisang, S. (2021). The Measurement of Service Quality at Linow Lake Tourist Attraction Using Servqual Method. International Journal of Tourism and Hospitality, 4 (2), 1-12. https://doi.org/10.32535/ijthap.v4i2.1110

3. Arcinas, M. M. (2021). A Blockchain Based Framework for Securing Students Educational Data. LINGUISTICA ANTVERPIENSIA, 4475-4484.

4. Asian Development Bank. (2007). Asian Development Outlook 2007: Growth Amid Change. Retrieved October 12, 2019 from https://www.adb.org/publications/asian-development-outlook2007-growth-amid-change

5. Barnes, D., Ponder, N. \& Dugar, K. (2011). Investigating the Key Routes to Customer Delight. Journal of Marketing Theory and Practice, 19(4), 359-375. https://doi.org/10.2307/23033925

6. Barnes, D.C., Collier, J.E., Howe, V. \& Douglas Hoffman, K. (2016). Multiple paths to customer delight: the impact of effort, expertise and tangibles on joy and surprise. Journal of Services Marketin, 30 (3), 277-289. https://doi.org/10.1108/JSM-05-2015-0172

7. Chang, P-L. \& Chieng, M-H. (2006). Building consumer-brand relationship: A cross-cultural experiential view. Psychology and Marketing, 23 (11), 927-959.

https://doi.org/10.1002/mar.20140

8. Charernnit, K., Alhourani, A. Q., Arcinas, M. M., Velasco, L. G., \& Alhourani, A. Q. Cognitive and Attitudinal Effects of Jigsaw Technique as a Collaborative Learning Strategy in Literature Teaching in the Philipines.

9. Danish Habib, M. \& Attiq, S. (2020). A model and empirical examination of influencing factors of customer satisfaction and service performance through interactional quality. Business \& Economic Review, 12(1), 119-138. https://doi.org/10.22547/ber/12.1.6

10.De Souza, R., Parveen, R., Chupradit, S., Velasco, L. G., Arcinas, M., Tabuena, A. C., ... \& Ventayen, R. J. M. (2021). Language Teachers' Pedagogical Orientations in Integrating Technology in the Online Classroom: Its Effect on Students Motivation and Engagement. Turkish Journal of Computer and Mathematics Education, 12.

11.Devi J, T. \& Lee Ross, D. (2003). A study of hotel guest perceptions in Mauritius. International Journal of Contemporary Hospitality Management, 15 (2), 105-115.

https://doi.org/10.1108/09596110310462959

12.DiPrieto, R. (2017). Restaurant and foodservice research: A critical reflection behind and an optimistic look ahead. International Journal of Contemporary Hospitality Management, 29(4), 12031234. https://doi.org/10.1108/IJCHM-01-2016-0046

13.Dominici, G. \& Palumbo, F., (2013). The Drivers of Customer Satisfaction in the Hospitality Industry: Applying the Kano model to Sicilian Hotels. International Journal of Leisure and Tourism Marketing, 3 (3). https://doi.org/10.1504/IJLTM.2013.052623 
14.Hartono, D.S., Wiranto, J.C., Aditama, R.G. \& Abdulrahman, A. (2018). Developing Marketing Strategy of Nasatech Kitchen Set Malang to Enter a New Market in USA. International Journal of Applied Business and International Management, 2 (2), 101-117. https://doi.org/10.32535/ijabim.v2i2.15

15.Ineson, E.M., Rhoden, S., Nita, V. \& Alexieva, I. (2011). Seeking excellent recruits for hotel management training: an intercultural comparative study. Journal of Hospitality and Tourism Education, 23 (2), 5-13. https://doi.org/10.1080/10963758.2011.10697001

16.Iyer, P., Davari, A., Srivastava, S. \& Paswan, A. K. (2020). Market orientation, brand management processes and brand performance. Journal of Product \& Brand Management, 30(2), 197-214. https://doi.org/10.1108/jpbm-08-2019-2530

17.Jian, O., Ahmad, S., Sin, L., Hoo, C., Hung Kee, D., Hao, J., Chun, L., Wee, L., Valentine, D., Azhar, M., Abdullah, N. \& Rajendran, J. (2021). International Journal of Tourism and Hospitality, 4 (2), 57-68. https://doi.org/10.32535/ijthap.v4i2.1057

18. Kimpakorn, N. \& Tocquer, G. (2009). Employees' commitment to brands in the service sector: Luxury hotel chains in Thailand. Journal Brand Management, 16, 532-544.

https://doi.org/10.1057/palgrave.bm.2550140

19.Kumar, A., Olshavsky, R., \& King, M. (2001). Exploring Alternative Antecedents of Customer Delight. The Journal of Consumer Satisfaction, Dissatisfaction \& Complaining Behavior, 14, 14. https://www.semanticscholar.org/paper/Exploring-Alternative-Antecedents-of-Customer-KumarOlshavsky/97c0d16bc92a0b2f2226082ecc4e63513dadd3b6

20.Kwong, K., \& Yau, O.H. (2002). The Conceptualization of Customer Delight: A Research Framework. Asia-Pacific Management Review, 7, 255-265.

https://www.researchgate.net/publication/265755253_The_Conceptualization_of_Customer_Del ight_A_Research_Framework

21.Lopez, K. R. B., Gaticales, N. P., Provido, A. V. C., Santelices, S. M. B., \& Arcinas, M. M. (2021). Social Contagion of Astrology in the Social Media amid COVID-19 Pandemic. International Journal of Multidisciplinary: Applied Business and Education Research, 2(4), 349-363.

22.Lopez, K. R. B., Gaticales, N. P., Provido, A. V. C., Santelices, S. M. B., \& Arcinas, M. M. (2021). Social Contagion of Astrology in the Social Media amid COVID-19 Pandemic. International Journal of Multidisciplinary: Applied Business and Education Research, 2(4), 349-363.

23. Magulod Jr, G. C. (2017). Factors of school effectiveness and performance of selected public and private elementary schools: implications on educational planning in the Philippines. Asia Pacific Journal of Multidisciplinary Research, 5(1), 73-83.

24.Magulod Jr, G. C. (2019). Learning styles, study habits and academic performance of Filipino University students in applied science courses: Implications for instruction. JOTSE: Journal of Technology and Science Education, 9(2), 184-198.

25.Magulod, G. C., Capulso, L. B., Dasig, J. P., Baluyot, M. B. B., Nisperos, J. N. S., Reyes-Chua, E., \& Chupradit, S. (2021). Attainment of the Immediate Program Graduate Attributes and Learning Outcomes of Teacher Candidates towards Global Competence Initiatives. International Journal of Learning, Teaching and Educational Research, 19(12).

26.Magulod, G. C., Capulso, L. B., Tabiolo, C. D. L., Luza, M. N., \& Ramada, M. G. C. (2020). Use of technology-based tools in ensuring quality of publishable journal articles. Int $J$ Learn Teach Educ Res, 19, 145-162

27.Magulod, G. C., Capulso, L. B., Tabiolo, C. D. L., Luza, M. N., \& Ramada, M. G. C. (2020). Use of technology-based tools in ensuring quality of publishable journal articles. Int J Learn Teach Educ Res, 19, 145-162.

28.Markovic, S., Raspor, S. \& Dorcic, J. (2011). What are the Key Dimensions of Restaurant Service Quality? An Empirical Study in the City Restaurant Settings. Sustainable Tourism: Socio-Cultural, Environmental and Economics Impact, 235-249.

https://www.researchgate.net/publication/256037727_What_are_the_Key_Dimensions_of_Rest aurant_Service_Quality_An_Empirical_Study_in_the_City_Restaurant_Settings 
29.Namkung, Y.\& Jang, S.C. (2013). Effects of restaurant green practices on Brand equity formation: Do green practices really matter?, International Journal of Hospitality Management, 33, 85-95. https://doi.org/10.1016/j.ijhm.2012.06.006

30.Nduba, C. \& Supinit, V. (2015). Measuring Customers Perceptions of Service Quality (Servqual) Towards Eat Me Restaurant, Silom, Bangkok, Thailand. International Journal of Social Science and Humanities Research, 3(4), 357-362. https://researchpublish.com/issue/IJSSHR/Issue-4-October2015-December-2015/3

31.Nuncio, R. V., Arcinas, M. M., Lucas, R. I. G., Alontaga, J. V. Q., Neri, S. G. T., \& Carpena, J. M. (2020). An E-learning outreach program for public schools: Findings and lessons learned based on a pilot program in Makati City and Cabuyao City, Laguna, Philippines. Evaluation and Program Planning, $82,101846$.

32.Pandey, R., Rao, K.S., Er, C., Hung Kee, D., Chua,W., Hon,H., Tan,C., Tayal,S., Sariya,S. \& Narendath, P. (2021). A Case Study of Consumer Satisfaction of Kentucky Fried Chicken. International Journal of Tourism and Hospitality, 4 (2), 98-111. https://doi.org/10.32535/ijthap.v4i2.1060

33.Parasuraman, A., Zeithaml, V.A. \& Berry, L.L. (1988). SERVQUAL: A multiple- Item Scale for measuring consumer perceptions of service quality. Journal of Retailing, 64 (1), $12-40$. https://www.researchgate.net/publication/225083802_SERVQUAL_A_multiple_Item_Scale_for_measuring_consumer_perceptions_of_service_quality

34.Qin, H. \& Prybutok,V. (2009). Service Quality, Customer Satisfaction and Behavioral Intentions in Fast-Food Restaurants. International Journal of Quality and Service Sciences, 1 (1), 78-95. https://doi.org/10.1108/17566690910945886

35.Rao, S. \& Sahu, P. (2013). Impact of Service Quality on Customer Satisfaction in Hotel Industry. Journal of Humanities and Social Science, 18 (5), 39-44. http://doi.org/10.9790/0837-1853944

36.Ryu, K., Lee, H. \& Gon Kim, W. (2012). The influence of the quality of the physical environment, food, and service on restaurant image, customer perceived value, customer satisfaction, and behavioral intentions. International Journal of Contemporary Hospitality Management, 24 (2), 200223. https://doi.org/10.1108/0959611121120614

37.Saad Andaleeb, S. \& Conway, C. (2006). Customer satisfaction in the restaurant industry: an examination of the transaction-specific model. Journal of Services Marketing, 20 (1), 3-11. https://doi.org/10.1108/08876040610646536

38.Telukdarie, A., Munsamy, M., \& Mohlala, P. (2020). Analysis of the Impact of COVID-19 on the Food and Beverages Manufacturing Sector. Sustainability, 12(22), 9331. https://doi.org/10.3390/su12229331

39.Torres, E. \& Kline, S. (2012). From customer satisfaction to customer delight: Creating a new standard of service for the hotel industry. International Journal of Contemporary Hospitality Management, 25 (5), 642-659. https://doi.org/10.1108/IJCHM-Dec-2011-0228

40.Verdict Media Limited. (2020). COVID-19 pandemic to have a devastating impact on foodservice operators: Poll. Retrieved from https://www.verdictfoodservice.com/news/covid-19-impactdevastating-on-food-service-operators/ on October 2, 2020

41.Verma, H. V. (2003). Customer Outrage and Delight. Journal of Service Research, 3 (1) 119133.https://www.proquest.com/docview/195555358/fulltextPDF/54F9805B30446EPQ/1?account id $=38643$

42.Wilkins, H., Merrilees, B. \& Herington, C. (2007). Towards an understanding of total service quality in hotels. International Journal of Hospitality Management, 26 (4), 840-853.

https://doi.org/10.1016/j.ijhm.2006.07.006 